DOI:10.24193/tras.SI2018.2

Published First Online: 2018/12/28

\section{THE THORNY ROAD \\ TO PUBLIC ADMINISTRATION REFORM IN MONTENEGRO}

\author{
Dražen CEROVIĆ \\ Gordana GASMI \\ Dragan PRLJA
}

the country to harmonize its legislation with the EU acquis communautaire. In reference to public administration, the Agreement's provisions emphasize the development of an efficient and accountable public administration with the goal of modernizing the Montenegrin administration in line with standards and principles of the European Administrative Space. In 2003, Montenegro adopted the PARiM Public Administration Reform Strategy 2003-2009 with two priorities: institutional and legal consolidation of the administrative system and the harmonization of the existing legislation with European and international standards (EU, CoE, UN, OSCE). However, the PARiM project met resistance and was not fully realized. The following administrative reform strategy, called Agenda of Administrative Reforms in Montenegro 2011-2016 (AURUM), states that Montenegro is determined to become part of the European system of values and that public authorities should fully harmonize the national legal framework with the acquis communautaire. In the 2016-2020 Public Administration Strategy, it was noted that AURUM had achieved limited effects and that the EU candidate countries need to establish an effective and efficient public administration. With all the drawbacks and obstacles that the public administration reform in Montenegro faced and is facing, the adoption and implementation of the new Law on Administrative Procedure (2014-2017) opened up prospects that public administration reform to be achieved on Montenegro's road to full EU membership.

Keywords: public administration reform, Law on Administrative Procedure, candidate country, EU accession, Montenegro.

\author{
Dražen CEROVIĆ (Corresponding author) \\ Associate Professor, Faculty of Law, \\ University of Montenegro, Podgorica, Montenegro \\ Tel.: 00382-20-238.604 \\ E-mail: drazen.cerovic@protonmail.ch
}

\section{Gordana GASMI}

Professor, University 'Dositej', Belgrade, Serbia

Senior Research Fellow, Institute of Comparative Law, Belgrade, Serbia

Tel.: 00381-11.32.33.213

E-mail: gordana.gasmi@gmail.com

\section{Dragan PRLJA}

Research Fellow, Institute of Comparative Law, Belgrade, Serbia

Tel.: 00381-11-32.33.213

E-mail:dprlja@gmail.com 


\section{Introduction}

Montenegro is an independent post-Yugoslav multi-ethnic state in the Western Balkan region of Southeastern Europe, with a coast on the Adriatic Sea and bordering Croatia, Bosnia and Herzegovina, Serbia, Kosovo and Albania. Podgorica is the capital and the largest city, while Cetinje has the status of the Old Royal Capital.

Classified by the World Bank as an upper middle-income country, Montenegro is a member of the United Nations (UN), the World Trade Organization (WTO), the Organization for Security and Co-operation in Europe (OSCE), the Council of Europe (CoE) and the Central European Free Trade Agreement (CEFTA), the Union for the Mediterranean (UfM) and NATO.

On the basis of an independence referendum, Montenegro declared independence in 2006, and after adopting a new constitution in 2007 it became 'Montenegro - an independent and sovereign state, with the republican form of rule; a civil, democratic, ecological and state of social justice, based on the rule of law' (Constitution of Montenegro, 2007).

\section{European integration and public administration reform}

From the perspective of analytical methodology, the issue of administrative reform in Montenegro and its relevance to Montenegro's EU accession process needs to be viewed in the context of a general theoretical and conceptual framework. There is an abundance of literature and scientific sources on administrative reform in general and, in particular, on administrative reform in European countries. A short overview of recent publications on such topic(s) shows a variety of approaches and recommendations on this issue, including implications of the administrative reform process for Central and East European countries, shortcomings and successful implementation of reform strategies and action plans, policy 'lessons learned', etc. ${ }^{1}$

The following quote illustrates the dilemmas regarding the general theoretical and conceptual framework of administrative reform:

'Since much of the literature on administrative reform has been devoted to public administration, most examples and illustrations are drawn from the public sector. In contrast to many other areas of administrative theory, where analysis is based almost exclusively on business practices, the general analysis of administrative reform is more applicable on public administrative reform. (...) Successful reform in the administrative system may set in motion a whole series of chain events that lead to other kinds of reform, and those reforms in turn may indicate the need for further administrative reforms' (Caiden, 2011, p. 11).

1 See also other sources on administrative reform in general and in European countries (selection): Caiden, 2011; Nemec and Peters, 2010; Koprić and Kovač, 2017; Nemec, 2016; Kuhlmann and Wollmann, 2014; Hammerschmid et al., 2016; Nemec, 2007; Kattel, Mikulowski and Peters, 2011. 
On the other hand, the following quote illustrates the issues regarding administrative reform in the context of EU integration:

'European Administrative Space (EAS) has been recognised as a unique concept in the late nineties to meet the needs of EU enlargement as a complement to the acquis communautaire in the field of public administration and the improvement of national administrative law and administrative capacity. (...) Today, EAS represents more than that, since it incorporates fundamental principles to be followed by all administrators globally. EAS is an important tool in the absence of a formal EU acquis in the field of public administration, but leads to a necessary integration of EU values, goals, activities and methods to enable effective and equitable implementation of EU legal order. (...) The essence of the EAS is hence not the unification in terms of identical national standards for administrative organisations and procedures, but harmonisation of administrative bodies in relation to public services users' (Koprić and Kovač, 2017, pp. 9-11).

At the European Union (EU) - Western Balkans Summit 'Moving towards European Integration', held in Thessaloniki in 2003, Montenegro joined other countries of the region in 'sharing the objectives of the economic and political union in looking forward to joining the EU'. Pursuant to the conclusions of the Thessaloniki Summit, a special mechanism called the Stabilization and Association Process (SAP) was established as the framework for the European course of the Western Balkan countries. The process and the prospects SAP offers serve as an anchor for the reform in the Western Balkans, in the same way the accession process has done in Central and Eastern Europe. Progress of each country towards the EU will depend on its own merits in meeting the SAP conditions which are reviewed by the European Commission in the periodic 'country progress reports'.

Due to the 'slow pace' of the enlargement process that 'stems not only from the internal situation in the Balkan states, but also from the activities of the EU itself (...) which have caused its neighbourhood policy (including towards the Balkans) to lose a great deal of importance' (Szpala, 2018, p. 2), with only Croatia becoming an EU member, despite these countries' formal progress to accession, the follow-up EU Western Balkans Accession Summit took place some 15 years later (in Sofia, in 2018).

In the mean time, in 2014, Germany initiated the 'Berlin Process' as an intergovernmental platform for cooperation with the countries of the Western Balkans, in which Austria, France, Germany, the United Kingdom, Italy, Croatia, Slovenia, Albania, Bosnia and Herzegovina, Montenegro, Kosovo, Macedonia and Serbia participated. As part of this process, annual summits attended by EU representatives and heads of state and government of the Western Balkans counties were subsequently held in the 2014-2018 period.

In this context, the European Commission presented a document titled 'A Credible Enlargement Perspective for an Enhanced EU Engagement with the Western Balkans' in which, inter alia, the issue of administrative reform was emphasized as 
a relevant factor for future EU membership of the Western Balkans counties, which concluded that:

'The rule of law must be strengthened significantly. Today, the countries show clear elements of state capture, including links with organised crime and corruption at all levels of government and administration, as well as a strong entanglement of public and private interests. (...) A visibly empowered and independent judiciary and accountable governments and administrations are essential for bringing about the lasting societal change that is needed' (European Commission, 2018, p. 3).

Montenegro and the EU signed the Stabilization and Association Agreement (SAA), committing the country to harmonize its legislation with the EU acquis communautaire (2007). The aims of the association between the EU and Montenegro, inter alia, include: support to the efforts of Montenegro to strengthen democracy and the rule of law; to contribute to political, economic and institutional stability in Montenegro; to support the efforts of Montenegro in the approximation of its legislation to that of the EU; to support the efforts of Montenegro to complete the transition into a functioning market economy; to foster regional cooperation in all the fields covered by the Agreement (art. 11, SAA, 2010).

In reference to public administration, the SAA contains a special provision emphasizing that cooperation shall aim at ensuring the development of an efficient and accountable public administration in Montenegro, notably to support rule of law, the proper functioning of the state institutions for the benefit of the entire population of Montenegro and the smooth development of the relations between the EU and Montenegro. Cooperation in this area shall mainly focus on institution building, including the development and implementation of transparent and impartial recruitment procedures, continued training and the promotion of ethics within the public administration, and shall cover all levels of public administration, including local administration (art. 114, SAA, 2010).

In the context of the signed SAA, the Government of Montenegro adopted the National Program for Integration (NPI) of Montenegro into the EU (2008), which contained detailed activities necessary for EU membership, represented 'a strategic frame of democratic and economic reforms in the country' (NPI, 2008, p. 19). In the same year, Montenegro applied for EU membership and completed the European Commission questionnaire (2009). Reviewing Montenegro's application, in its Opinion, the European Commission concluded favorably, and recommended Montenegro as candidate country in 2010. The European Council granted Montenegro EU candidate-country status in 2011, and accession negotiations with Montenegro began in 2012, with thirty one chapters opened (European Commission, 2010a, p. 11). ${ }^{2}$

2 Furthermore, Montenegro enjoys widespread support among EU member states' officials, and accession of the country to the EU is considered possible by 2025. In its 2016 assessment of the 
However, in its Opinion the European Commission indicated that Montenegro had to prove its strong commitment to seven key priorities (in the field of political criteria for EU membership) and in particular to 'complete essential steps in public administration reform including amendments to the law on general administrative procedure and the law on civil servants and state employees and the strengthening of the human resources management authority and the state audit institution, with a view to enhancing professionalism and de-politicization of public administration and to strengthening a transparent, merit-based approach to appointments and promotions' (European Commission, 2010a, p. 11). As emphasized in regional studies on public administration reforms: 'As any complex system, PA is evolving over time. The contemporary society requires good administration in the sense of implementation of the EAS principles, but beyond the formal adoption of PAR strategies and new laws. The latter problem is present especially in Eastern Europe, with gaps due to the ongoing post-socialist transition, the lack of administrative capacity, and gradual but inconsistent reforms.' (Kovač and Jukić, 2017, p. 140).

\section{Institutional and political context}

Early administrative reforms in Montenegro during the 1990s were conditioned by specific political and economic factors. Politically, Montenegro was faced with challenges that came with the introduction of the post-communist multi-party system (1990), the consequences of the dissolution of the former Yugoslavia and the establishment of the Federal Republic of Yugoslavia with Serbia and Montenegro as the only two federal member states (1992) ${ }^{3}$. However, significant change in the political and economic orientation of Montenegro followed the 1998 parliamentary election when the country's political establishment pursued a new political agenda of restoring the country's independence with the aim of joining the 'euro-atlantic' integration process, including EU and NATO memberships.

In this volatile context, general institutional, political and economic reforms began in Montenegro (Kavran, 1999, p. 2) ${ }^{4}$. In regard to the administrative reforms the goal

accession progress, the European Commission identified Montenegro as having the highest level of preparation for membership among the negotiating states.

3 Of the six former federal Yugoslav republics only Slovenia and Croatia subsequently obtained EU membership (see also, Kovač and Jukić, 2017, pp. 127-145).

4 The turbulence caused with transition, ethnic tensions in South-Eastern Europe and the reaction of the international community created in Montenegro a heightened awareness of the need for accelerated political, economic and institutional change. At the recent elections (March 1998), the program of the reform oriented, ethnically tolerant coalition won convincingly over its opponent. The new government of Montenegro almost immediately has embarked on a new course. (...) There are serious frictions between the Federal Government in Belgrade and Montenegro. Cooperation and communications with the Federal Government in Belgrade are almost entirely blocked. In this situation, the Government of Montenegro has accelerated its reform agenda (Kavran, 1999, p. 2). 
was modernization of the Montenegrin administration in line with standards and principles of the European Administrative Space. However, due to the inherited economic and political situation, pro-active administrative reform started several years later, in 2003 (Marković, 2007, p. 37).

The public administration system in Montenegro in the 1992-2003 period was highly centralized and cumbersome, with the high number of civil servants and more ministries and agencies than it was really needed (e.g. in the 1998-2001 period Montenegro had 18 Ministries and 19 additional government agencies with a permanent growth rate of $25 \%$ of number of employees) (ESI, 2001, pp. 10-13). The strongest administrative decision-making centers were ministries, while local administrations had limited autonomy in decision-making (Institut Alternativa, 2012, p. 14).

\section{Administrative Reform Strategy 2003-2009 (PARiM)}

In March 2003 the Ministry of Justice of the Government of Montenegro adopted the first comprehensive Public Administration Reform Strategy 2003-2009 (PARiM), with two priorities and basic reform goals: (a) institutional and legal consolidation of the administrative system; (b) the harmonization of the existing legislation with widely recognized standards and principles of the most important international institutions i.e. EU, CoE, UN, OSCE, etc. (Blažić and Dujić, 2004, p. 84). A particular reason for the improvement and restructuring of the Montenegrin administrative system, as well as all other subsystems, comes from the 'unreserved and clear determination and devotion of this Government to join the European Union' and to become a part of other international integration processes (Ministry of Justice, 2003, p. 13, p. 18). As emphasized:

'Public administration has always been a domestic affair for EU Member States. At the same time, national public administrations have to implement EU directives and recommendations in such a way that European citizens are able to enjoy the rights granted to them by the EU Treaties, irrespective of the country in which they live; a fact which on its own could well justify the interest of the EU in ensuring that each national administration has comparable quality and professionalism and, therefore, in the administrative capacities of their Member States' (Cardona, 2009, p. 3).

The first Administrative Reform Strategy in Montenegro incorporated three areas of the administrative system: a) state administration, b) local self-government, and c) public services: public enterprises, public institutions, regulatory agencies (ReSPA, 2013, pp. 215-217).

A key principle set by this strategy is that ministries are administrative bodies with rights to develop internal and foreign policies (working on the preparation of legislation, strategies, projects, programs and international documents), while other administrative bodies primarily perform duties of enforcement and implementation of the legislation. This represented a significant change compared to the earlier concept that the ministries had the right to create and implement policy. 
During this period, the following laws were adopted: on public administration (2003), on inspection control (2003), on general administrative procedures (2003), on local self-government (2003), on Ombudsman (2003), on civil servants (2004, 2008), on salaries of public servants and employees (2004) (Dujić, 2004, p. 18). Also, a systematic adjustment of the regulations on public administration to the Constitution of Montenegro, the Code of Ethics for civil servants and employees was adopted in 2005, accompanied by seventeen by-laws necessary for the implementation of the aforementioned laws (Government of Montenegro, 2007, p. 3). In accordance with the new legislation, a number of new institutions were established: the Ombudsman, the Administrative Court and the Court of Appeals, the State Audit Institution. In order to improve human resources management in the civil service, in 2004 the Human Resources Management Agency was established (Blažić, 2006, p. 19).

During the period of the first administrative reform in Montenegro, coordination of the activities was headed by the prime minister, and the government regularly discussed analytical materials and operative issues ${ }^{5}$. However, the quality of the reporting and analytical material was inappropriate, as the materials considered mostly referred to legislative changes. These materials, inter alia, lacked relevant data and impact analysis reports on the adopted legislation. The absence of quality analysis on administrative reform activities proved to be a factor which impeded the drafting of the new reform strategy (Institut Alternativa, 2012, p. 23). Additionally, a Council on Administrative Reform was established and chaired by the Minister of Justice.

However, with the PARiM project the thorny road of administrative reform in Montenegro took off with resistance at several levels (Korać, 2016, p. 7). The Government itself admitted that the implementation of this strategy met resistance on several levels: by the heads of institutions - because of the fear that the merit-based system would deprive them of their privileges - and by public servants and employees because they did not know what changes the strategy would bring. Another problem was the lack of highly-qualified staff, as well as a lack of institutions which could analyze the process (Pajović, 2013, p. 217).

Following the independence and the formation of a new government after the parliamentary elections of 2006, public administration affairs were transferred from the Ministry of Justice to the newly established Ministry of Internal Affairs and State Administration. As a consequence, the Administrative Reform Council set up by the Ministry of Justice was abolished and a similar body was not set up by the new ministry, thus weakening the existing monitoring and implementation capacities and slow-

5 These materials include: Analysis of Reformed Legislation in the Field of Public Administration (January 2005); Information on the Activities of the Ministry of Justice in the Reform Process of the Judiciary, State Administration and Local Self-government (April 2005); Report on Activities to Create Conditions for the Implementation of New Administrative Legislation in Montenegro (September 2005); Report on the Status of Administrative Matters in 2005 (June 2006); Analysis of the Realization of the Public Administration Reform (May 2007). 
ing down the work on the new administrative reform strategy for the coming period. In this context, the drafting of the new administrative reform strategy in Montenegro began in early 2010 .

In 2010 Montenegro obtained the status of candidate country for EU membership following the positive evaluation in the Opinion of the European Commission on Montenegro's application for membership. The Opinion was accompanied by an Analytical Report (European Commission, 2010b).

In its Analytical Report, the European Commission referred to several critical issues regarding the public administration situation in Montenegro (e.g. a merit system for recruitment and promotion is neither clearly enshrined in the legislation, nor applied in practice; there is no comprehensive, regulatory framework to monitor corruption and conflict of interest through consistent internal controls) and concluded:

'Overall, the public administration remains weak and highly politicized. The general administrative framework, including the Law on general administrative procedure and the Law on civil servants and state employees needs to be reviewed and adapted to European standards and principles. Administrative procedures are cumbersome and time-consuming and must be simplified. Significant efforts are still necessary by Montenegro to establish a sound and accountable public administration free of politicization. The quality of legislation and of decisions and acts produced by the public administration needs to be considerably improved. Further considerable efforts to strengthen administrative capacity to deal with future EU accession obligations are needed' (European Commission, 2010b, pp. 14-16).

\section{Administrative Reform Strategy 2011-2016 (AURUM)}

The second administrative reform strategy in Montenegro was called Agenda of Administrative Reforms in Montenegro (AURUM) ${ }^{6}$. The first version of AURUM was a draft for the 2010-2014 period. This draft version received very critical remarks and comments (notably SIGMA and the EU). Therefore, this draft was significantly revised and subsequently the Government adopted a revised version of AURUM for 2011-2016 (Government of Montenegro, 2011a).

The AURUM 2011-2016 document states that Montenegro is determined to become part of the European system of values. Therefore, public authorities should be trained to fully develop and harmonize the national legal framework with the acquis communautaire and, based on its full implementation and capacity for application, of its own regulations to be eligible to effectively work within the European administrative space. As for the administrative reform objectives, the document states that the goal of the Strategy is efficient, professional, and service oriented public administration, serving the needs of the citizens and other social and business entities with identified specific objectives: (a) strengthening the rule of law by strengthening le-

6 AURUM is the Montenegrin acronym for 'Agenda upravnih reformi u Crnoj Gori'. 
gality and predictability of administrative procedures and decisions; (b) improving efficiency and cost-effectiveness of public administration; (c) improving the business environment while improving the quality of public services and reducing the administrative burden; (d) raising the level of ethics in public administration; (e) improving transparency and accountability of public administration; and (f) integrating Montenegro's public administration into the European Administrative Space (Government of Montenegro, 2011a, pp. 2-3).

The AURUM Strategy specifies several factors which have negative effects to achieve the set objectives: (a) resistance of the administration system to change in the initial stages of the reform process; (b) global economic crisis, resulting in the destabilization of public finances and the budget deficit; (c) absence of adequate mechanisms to improve the financial status of civil servants and motivate them for their work; (d) insufficient number of creative young staff with required professional qualifications; (e) perception of a high level of corruption in certain sectors and at positions susceptible to corruption; ( $\mathrm{f}$ ) insufficient promotion of reform activities and their significance; and $(\mathrm{g})$ absence of an organized and competent institution which would monitor the reform process from the professional and methodological viewpoint and act as logistics support (Government of Montenegro, 2011a, p. 9).

The thorny road to administrative reform in Montenegro continued in the AURUM period. In its assessment on Montenegro, SIGMA stated that:

'The development of this Strategy was largely driven by the perception that it was requested by donors and primarily by the EU integration process. The Government Council for Public Administration Reform had weak substantive capacities and did not succeed in producing a convincing and coherent reform agenda. The drafting of the AURUM was thus heavily dependent on input from outside sources and had limited inter-Ministerial co-ordination. This generates doubts and concerns on the will and capacity to implement it and on its sustainability' (SIGMA, 2011, p. 3).

In another report SIGMA concluded that the 'public administration reform process suffers from a lack of effective implementation mechanisms (...) not very promising preconditions for achieving results' (SIGMA, 2012, p. 4).

Similar considerations were put by the European Commission, which in this period continuously repeated nearly identical assessments of the public administration reform in Montenegro. In the 2011 Progress Report for Montenegro, the Commission referred to the state of public administration as 'the overall capacity of Ministries to produce high-quality legislation and impact assessments remains limited. The administrative capacity involved in coordination of European integration, including financial assistance, remains weak and needs to be substantially strengthened' (European Commission, 2011, p. 8). In the 2012 Progress Report the Commission states that 'the administrative capacity for the coordination of European integration, including financial assistance, needs to be further strengthened to meet the requirements of the accession negotiations' (European Commission, 2012, p. 8). In the 2013 Progress 
Report the Commission concludes that the 'overall capacity of Ministries to prepare high-quality legislation and impact assessments needs to be enhanced. As regards the local government, further efforts are needed to establish a transparent, efficient and accountable administration' (European Commission, 2013, p. 7).

The management and monitoring processes of the administrative reform at the central and local level in Montenegro was confused and uncoordinated (ReSPA, 2013, pp. 215-217). Neither the draft AURUM 2010-2014 Strategy nor the revised and adopted version of AURUM 2011-2016 resolved the issues of coordinating administrative reform activities at the state and local level. At local level, a special coordination Committee for Local Reform chaired by the Minister of Interior was responsible for the monitoring and managing the administrative reform activities of the local self-government units.

The management and monitoring processes of the administrative reform at the national level was more complicated. The AURUM 2010-2014 draft proposed the establishment of a Council for public administration reform as a high-level advisory body, commissioned to provide advice and strategic directions to the Government for the implementation of the AURUM Strategy, which is to be composed of government officials, prominent experts and representatives of the civil society and the donors. In addition, an operational team and an office for coordination were proposed (Government of Montenegro, 2010, p. 43). However, the adopted version of AURUM 2011-2016 Strategy provided for a significantly different management and monitoring model (Government of Montenegro, 2011b, pp. 52-53).

The adopted AURUM 2011-2016 Strategy provided that the monitoring and management of the administrative reform efforts are to be entrusted to the existing Council for Regulatory Reform and Improving Business Environment (central administration) and to the Coordination Committee for Local Government Reform (local level). The Council and the Coordination Committee in their respective areas are to: (a) monitor and coordinate activities of administrative bodies and other relevant institutions to follow the implementation; (b) encourage cooperation among state authorities, municipalities, non-governmental organizations, international organizations and other parties to the process; (c) assess the progress and give proposals for specific further actions to be taken; (d) set guidelines and directions for decentralization of the public administration system; (e) assess the impacts of laws and other legislation relevant to administrative reform, identify obstacles and render proposals to overcome them; and (f) consider other administrative reform issues of improving the efficiency of implementation.

The strategy prescribed that the progress reports to be submitted every six months to the Council and the Coordination Committee by the authorities carrying out tasks for them, as well as that the progress reports to be submitted every six months by the Council and the Coordination to the Government of Montenegro.

It is important to point out that the Council's tasks do not specifically include PAR competences, although it is an integral part of the reform efforts as the Council 
predominantly deals with the business sector and financial aspects of governing the business relations (Decision on Establishing the Council for Regulatory Reform and Improving the Business Environment, 2010). The Council is a sixteen-members body, which includes the Prime Minister and six ministers (e.g. Justice, Interior, Finance, Economy, Sustainable Development, Tourism), as well as members from the Chamber of Commerce, employers' association, business alliance, union of municipalities, and the Commercial Court.

Within the Government, operational management of the implementation of the Strategy is not clear and 'rests somewhere between the Ministry of Interior (having lost, meanwhile, the 'public administration' nomination) and the Ministry of Finance, which is not a good solution, since it leads to the division of responsibilities and unclear shared responsibility' (Institut Alternativa, 2012, p. 44).

\section{Public Administration Reform Strategy 2016-2020}

The Public Administration Reform Strategy of Montenegro 2016-2020 was adopted by the Government of Montenegro in July 2016. The drafting of the Public Administration Reform Strategy of Montenegro 2016-2020 began at the end of 2014 in cooperation with SIGMA/OECD experts and through consultations with responsible government and non-government institutions.

The 2016-2020 Strategy takes into account assessments of the state of the public administration presented in the Analysis of the Effects of the Implementation of AURUM adopted by the Government in June 2015. By analyzing the available data, it was generally noted that significant activities in achieving the objectives defined by the AURUM have been realized, but also that limited effects have been achieved. As stated in the strategy: 'Additional efforts should be invested in order to improve public administration at all levels. National strategies represent crucial documents with the task to recognize key challenges the EU candidate countries are faced with, while trying to establish an effective and efficient public administration' (Government of Montenegro, 2016).

The structure of the 2016-2020 Strategy follows the logic of reform areas as they are laid down in the 'Principles of Public Administration', developed by SIGMA. These principles represent the standards of the so-called soft acquis and serve as a framework for the assessment of the present state and the progress made in the area of public administration. "The priority of the public administration reform will be to improve competitiveness of the economy and to raise the quality of the Montenegrin citizens' lives, and also to meet the requirements for the EU membership' (Government of Montenegro, 2016, p. 5).

With this mission in mind, Montenegro prepared and adopted a new Law on Administrative Procedure (LAP) in line with the standards of the rule of law and principles of good governance common to the Member States of the EU (Ivanović, 2014, p. 24). With the new LAP, the administrative procedure was reformed in compliance with the standards of the European Administrative Space. In the period until June 
2016 the texts of the Strategy and Action Plan were aligned in accordance with the European Commission proposals.

In its 2016 Report on Montenegro, the European Commission addressing the public administration reform stated that:

'Montenegro is moderately prepared with the reform of its public administration. Some progress has been made, notably with the adoption of the public administration reform Strategy 2016-2020. (...) by means of a consultative and transparent process. There is a political support for the reform, which was also declared as a priority in the Government's structural reform plan. Consistent political support will be needed to implement the Strategy, e.g. for measures to rationalize the administration, while ensuring capacity for European integration' (European Commission, 2016, pp. 9-12).

In the Report, a specific reference was made to the administrative procedures:

'Simplification of administrative procedures is ongoing. Sectoral laws containing over hundred and fifty special procedures are being gradually brought into line with the Law on Administrative Procedures, but a substantial workload remains. So far, amendments to eighty laws have been drafted, and they are in various stages of adoption (European Commission, 2016, pp. 9-12).

\section{Administrative procedure in the context of an administrative reform in Montenegro}

A new chapter of administrative procedure in Montenegro was opened in late 2014, when the national Parliament adopted the new Law on Administrative Procedure. The Public Administration Reform Strategy indicates that the new LAP is 'service-oriented towards the users of administrative services harmonized with the best comparative practices in this area through a large number of novelties' (Government of Montenegro, 2016, p. 13). Successful implementation of new legal solutions will depend on meeting certain preconditions, including the training of civil servants who conduct administrative procedures and the harmonization of the rules of procedures in specific laws: this is an on-going process.

The basis for adopting a new Law on Administrative Procedure rests on a completely redefined role of the public administration in accordance with the principles and standards of the European Administrative Space, underlining its gradual but decisive transformation from the 'administration as an instrument of Government' model to the 'administration as public service to citizens' model, based on issues of public interest in administrative procedures and the stability of institutions that guarantee democracy, the rule of law and human rights' (Lilić, 2017, p. 29). The fundamental innovation in the new LAP was the redefinition of the existing 'general administrative procedure', which produced a voluminous, inefficient and often contradictory body of 'special administrative procedures', into a more functional and simple 'administrative procedure' (Ivanović, 2015, p. 37). 
Due to the numerous innovations introduced by the new LAP (administrative contacts, guarantee acts, providing public services, objection as new legal remedy, etc), its entry into force was set for January 1, 2016 (Law on Administrative Procedure, 2014). However, this timeline was first prolonged to July 1, 2016, and subsequently to July 2017, as preliminary analysis indicated that around 367 laws containing special administrative procedures had to be harmonized with the new LAP (Parliament of Montenegro, 2014) ${ }^{7}$. The previous LAP showed serious limitations in administrative procedures regarding the interests of the citizens. Certain aspects of the special administrative procedures needlessly differed from the general standards having as consequence more complicated and expensive situations and reduced legal certainty for the interested parties (Lilić and Cerović, 2013, p. 82; Lilić, 2012, pp. 221-222; Dimitrijević and Blažić, 2008, p. 34; Sekulić, 2004, p. 46).

The new LAP was adopted with the goal of achieving standards of 'good governance' and 'good administration' serving the citizens with public services rendered by the public administration (Council of Europe, undated). In this context, the main motives for adopting a new LAP were a new concept of 'administrative matter' (Lilić, 2006, p. 54), simplification and expediency of the procedure, reducing expenses for all parities, upgrading procedural mechanisms, introducing e-Government solutions and efficient protection of public interest and the concerned parties.

Apart from being quality legislation fulfilling the harmonization goal to the EU membership, the most important aspect of the new LAP still remains to be met, inter alia, the alignment of special administrative procedures which will enable the full realization of the new LAP in the everyday practice (Cerović, 2016, p. 39). Furthermore, many changes in the administrative procedure, introduced by the new LAP, have a common goal in combating abuses and potential corruption, including:

- The affirmation of good governance standards in administrative procedure applied in the EU, meaning that the public administration is a service-oriented authority providing public service to the citizens as clients. The administrative public services are now rendered by 'public authorities' and not by 'state organs';

- The procedure is conceived on efficiency, speed and low expenses within the framework of protecting public interest and the interests of the concerned parties.

- The new LAP definitely departs from the previous theoretical model and practical concept that the state administration has the exclusive possession of 'monopoly on physical force'. The resistance to the model of the administration as a public service is a relict of the doctrine of 'state and law' as two sides of the same coin (Lilić, 2010, p. 87). The burden of this concept that for many years had prevailed in the Western Balkans was the main obstacle to the modernization of the

7 E.g. 'annulment' of administrative acts had to be revised in 138 laws; 'rejection' in 32 laws; 'conclusion' in 31 laws; 'finality' in 25 laws; 'special appeal' in 4 laws; 'vital impairment of procedure' in 6 laws, etc). 
administrative system and conditioned numerous abuses, corruptive activities and collateral damage to the public and private interests.

- The new LAP gives a definition of an 'administrative matter' which refers not only to the traditional issue of deciding on the rights and obligations of the parties, but also refers to the additional administrative activities (e.g. administrative contracts, guarantee acts, providing public services, etc).

- The new LAP stipulates that the second instance authority may decide only once on a particular matter, avoiding a wide-spread 'ping-pong' practice of referring the matter back to the first instance.

- A particular feature of the new LAP is the introduction of the 'positive option' in case the administrative authority fails to act. If the public administrative authority does not decide on a submission in due time, the presumption is that the request was fulfilled. The previous opposite practice (i.e. that in the case of failing to act, the presumption was that the request was denied) was the cancer-cell of many administrative procedures, in direct violation of the rights and legitimate expectation of the citizens.

- Electronic communication between the public authority and the party in an administrative procedure is a significant innovation in the new LAP.

- The new LAP has significantly reduced the provisions on hearings and presenting evidence in administrative procedures, with a simple and efficient analogy clause, which stipulates the use of the detailed provisions on this matter in the Law on Civil Procedure.

\section{Conclusions}

From the initial PARiM activities in the 2003-2009 period, the thorny road of public administration reform in Montenegro steered through meager results of the 20112016 AURAM sequence and is proceeding on the action plans of the current 20162020 Public Administration Reform Strategy. The cumbersome system of public administration in Montenegro, the large number of public servants and staff, resistance to reform and change, insufficient information technology ability, the interference of politics in administrative affairs and political instability in the 1997-2000 period, followed by the 2000-2006 period of social and economic uncertainty preceding the referendum on independence and the 2008 world financial crisis, as well as the tensions preceding NATO membership - have all considerably restricted the endeavors for a sustainable European Administrative Space oriented public services to citizens model of the public administration in Montenegro in the past decade and a half.

A significant step on this thorny road in achieving European standards of public administration reform in Montenegro, however, has been charted by adopting and consequently implementing the new Law on Administrative Procedure in 2014-2017. With all the drawbacks and obstacles that the public administration reform in Montenegro faced and is still facing, the adoption and implementation of the new Law on Administrative Procedure opens up the prospects that a comprehensive and sus- 
tainable public administration reform is not only conceivable, but also achievable on Montenegro's road to full EU membership.

\section{References:}

1. Blažić, Đ., Službenički sistem (The Civil Service System), Podgorica: Uprava za kadrove, 2006.

2. Blažić, Đ. and Dujić, S., Osnovi sistema javne uprave u Crnoj Gori (Basic Elements of the Public Administration System in Montenegro), Podgorica: PARiM Projekt, 2004.

3. Caiden, G.E., Administrative Reform, London: Transaction Publishers, 2011.

4. Cardona, F., Integrating National Administrations into the European Administrative Space, Conference on Public Administration Reform and European Integration, Budva, Montenegro, SIGMA, 2009.

5. Cerović, D., 'Analiza novog crnogorskog Zakona o upravnom postupku' (Analysis of the New Montenegrin Law on Administrative Procedure), 2016, Uprava i javna politika, Institut za političke studije, vol. 6, no. 3, pp. 27-38.

6. Constitution of the Republic of Montenegro, published in the Official Gazette of the Republic of Montenegro no. 48 of 1992.

7. Constitution of Montenegro, published in the Official Gazette of Montenegro no. 01 of 2007.

8. Council of Europe, 'Good Governance', undated, [Online] available at https://www. coe.int/en/web/good-governance, accessed on April 30, 2017.

9. Decision on Establishing the Council for Regulatory Reform and Improving the Business Environment, published in the Official Gazette of Montenegro no. 9 of 2010.

10. Dimitrijević, P. and Blažić, Đ., Upravno pravo Crne Gore (Administrative Law of Montenegro), Podgorica: Fakultet za državne i evropske studije, 2008.

11. European Commission, 'Commission Opinion on Montenegro's application for membership of the European Union', COM(2010) 670, Brussels, 2010a.

12. European Commission, 'Analytical Report Accompanying the Commission Opinion on Montenegro's Application for Membership of the European Union', COM(2010) 670, Brussels, $2010 \mathrm{~b}$.

13. European Commission, 'Montenegro 2011 Progress Report', SEC(2011) 1204 final, Brussels, 2011.

14. European Commission, 'Montenegro 2012 Progress Report', COM(2012) 600 final, Brussels, 2012.

15. European Commission, 'Montenegro 2013 Progress Report', COM(2013) 700 final, Brussels, 2013.

16. European Commission, 'Montenegro 2016 Report', SWD(2016) 360 final, Brussels, 2016.

17. European Commission, 'A Credible Enlargement Perspective for an Enhanced EU Engagement with the Western Balkans', $\operatorname{COM}(2018)$ 65, Strasbourg, 2018.

18. Government of Montenegro, 'Analysis of Implementing the Public Administration Reform Strategy', Podgorica, 2007.

19. Government of Montenegro, 'National Plan for Integration of Montenegro in the EU for the Period 2008-2012', Podgorica, 2008. 
20. Government of Montenegro, 'Agenda for Public Administration Reform in Montenegro for 2010-2014, 'AURUM” - Draft, 2010.

21. Government of Montenegro, 'Strategy of Public Administration Reform in Montenegro 2011-2016 - 'AURUM", Podgorica, 2011a.

22. Government of Montenegro, 'Agenda for Public Administration Reform in Montenegro for 2011-2016 - 'AURUM", $2011 b$.

23. Government of Montenegro, 'Public Administration Reform Strategy in Montenegro 2016-2020', Podgorica, 2016.

24. European Stability Initiative (ESI), 'Rhetoric and Reform: A Case-Study of Institution Building in Montenegro, 1998-2001', Podgorica and Berlin, 2001.

25. Hammerschmid, G., Van de Walle, S., Andrews, R. and Bezes, P. (eds.), Public Administration Reforms in Europe: The View from the Top, Cheltenham, UK: Edward Elgar Publishing, 2016.

26. Ivanović, S., Novi Zakon o upravnom postupku - Komentar sa registrom pojmova (The New Law on Administrative Procedure - Commentary with Index), Podgorica, 2015.

27. Ivanović, S., 'Novi Zakon o upravnom postupku' (New Law on Administrative Procedure), 2014, Bilten Vrhovnog suda Crne Gore, no. 2, pp. 18-29.

28. Kattel, R., Mikulowski, W. and Peters, G.B. (eds.), Public Administration in Times of Crisis, Bratislava: NISPAcee Press, 2011.

29. Kavran, D., Administrative Reform in Montenegro - Project Outline, $7^{\text {th }}$ NISPAcee Conference, Sofia , March, 1999.

30. Koprić, I. and Kovač, P. (eds.), European Administrative Space: Spreading Standards, Building Capacities, Bratislava: NISPAcee Press, 2017.

31. Korać, S., 'Javna uprava u moralnom procepu' (Public Administration in Moral Gap), 2016, Uprava i javna politika, Institut za političke studije, Beograd, vol. 6, no. 3, pp. 48-60.

32. Kovač, P. and Jukić, T., 'Declarations and Reality of Europeanized Public Administration in Eastern Europe: Journals Content Analysis in Slovenia and Croatia', 2017, Transylvanian Review of Administrative Sciences, no. 50E, pp. 127-145.

33. Kuhlmann, S. and Wollmann, H., Introduction to Comparative Public Administration: Administrative Systems and Reforms in Europe, Cheltenham, UK: Edward Elgar Publishing, 2014.

34. Law on Administrative Procedure, published in Official Gazette of Montenegro no. 56 of December 24, 2014.

35. Lilić, S. and Cerović, D., Upravno procesno pravo (Administrative Procedure Law), Podgorica: Pravni fakultet Univerziteta Crne Gore, 2013.

36. Lilić, S., Transformation of the Public Administration - From Instrument of Political Power to Rendering Public Services to Citizens, Beograd: Pravni fakultet, 2017.

37. Lilić, S., Upravno pravo Crne Gore (Administrative Law of Montenegro), CID, Podgorica, 2012.

38. Lilić, S., Uticaj sovjetske doktrine o državi i pravu (The Influence of the Soviet Doctrine of State and Law), Pravo i društvo, Beograd: Časopis za pravnu i politicku kulturu, 2010, pp. 82-91.

39. Lilić, S., Upravna stvar u svetlu tradicionalne doktrine i savremenog zakonodavstva (Administrative Matter in Light of Traditional Doctrine and Contemporary Legislation), Eastern Sarajevo: Law Faculty of the University of Eastern Sarajevo, 2006, pp. 89-105. 
40. Marković, M.I., Savremena javna uprava (Contemporary Public Administration), Podgorica: CID, 2007.

41. Ministry of Justice, Public Administration Reform Strategy in Montenegro 2002-2009, Podgorica, 2003, [Online] available at http://unpan1.un.org/intradoc/groups/public/ documents/untc/unpan012396.pdf, accessed on May 10, 2010.

42. Muk, S., Marovic, J., Maric, B., Popovic, M., Milosevic, M. and Sosic, M., State Administration Reform in Montenegro: Between Ambitious Plans and Real Possibilities, Podgorica: Institut Alternativa, 2012, [Online] available at http://media.institut-alternativa. org/2013/03/state-administration-reform-in-montenegro.pdf, accessed on June 13, 2018.

43. Nemec, J. (ed.), Europeanisation in Public Administration Reforms, Bratislava: NISPAcee Press, 2016.

44. Nemec, J., Lessons and Recommendations for Improvement: Central and Eastern European Public Administration and Public Policy, Bratislava: NISPAcee Press, 2007.

45. Nemec, J. and Peters, G.B. (eds.), State and Administration in a Changing World, Bratislava: NISPAcee Press, 2010.

46. Parliament of Montenegro, Standing Committee on the Political System Judiciary and Administration of the Parliament of Montenegro, 'Consultative Debate on the Draft Law on Administrative Procedure with Expert Consultants, Representatives of State Organs and the Representatives of the NGO Sector', Podgorica, September 25, 2014.

47. Rimkute, E., Trebicka, J., Buha, D., Djulabic, V., Halili, R., Gelevska, J., Djuric, D. and Vlajkovic, V., Regional Comparative Study on Methodologies Used for Preparation of Public Administration Reform Strategies in Western Balkans, Danilovgrad: ReSPA, 2013.

48. Sekulić, L., Osnovi upravnog prava (Fundamentals of Administrative Law), $2^{\text {nd }}$ edition, Podgorica: University of Montenegro, 2004.

49. SIGMA, 'Assessment Montenegro', 2011, [Online] available at www.sigmaweb.org/ publications/48970665.pdf, accessed on October 20, 2012.

50. SIGMA, Assessment Montenegro, Civil Service and Administrative Law, 2012.

51. Szpala, M., 'A New Opening in Relations Between the EU and the Western Balkans', Centre for Eastern Studies, no. 267, 2018, [Online] available at https://www.osw.waw. pl/sites/default/files/commentary_267_0.pdf, accessed on May 5, 2018.

52. Stabilization and Association Agreement between the European Communities and Their Member States, of the one part, and the Republic of Montenegro, of the other part, published in the Official Journal of the European Union, no. OJL108/1 of April $29,2010$. 